\title{
PREPARATION OF BRIQUETTES ON THE BASIS OF SUB-STANDARD COAL OF KAZAKHSTAN FIELDS
}

\author{
Marat Tulepov1,2, Larissa Sassykova1, 2, ${ }^{1}$, Almagul Kerimkulova1,2, \\ Gulmira Tureshova1, 2, Fedosya Abdrakova1, 2, Anar Zhapekova1, \\ Zukhra Sultanova1, Galiya Spanova1, Dana Tolep ${ }^{1,2}$, Sholpan Gabdrashova ${ }^{1,2}$, \\ Dauren Baiseitov ${ }^{1,2}$
}

https://doi.org/10.23939/chcht16.01.118

\begin{abstract}
A technology of briquetting of sub-standard coal of Kazakhstan fields to obtain high-quality briquetting fuel has been developed. A modifying additive in the form of oil residues has been selected, that make it possible to obtain a binder composition for brown coal briquetting. The material for the preparation of coal briquettes is coal fines from dry, poorly sintered coals, which cannot be used for direct combustion in the furnace. The optimal parameters for obtaining high-quality fuel briquettes have been determined. The introduction of a modifying additive into the oil residues makes it possible to obtain a binder composition for briquetting brown coal. Studies of the physical parameters of briquettes and the data of SEM showed that the thickness of the adsorption layer of coal and the cohesion of the binder in thin layers play an important role in the formation of the structure and strength of the briquette. It was assumed that at the optimum thickness of the film layer, the maximum manifestation of capillary forces and an increase in the adhesive interaction between the particles and the binder take place. The organic component of the coal fines is a mixture of various X-ray amorphous components, the presence and number of which vary in a series of metamorphism. The results of the performed studies show the possibility and prospects of using local raw materials for the development of high-quality briquetted brown coal fuel.
\end{abstract}

Keywords: coal, briquetting, binder, tar, calorific value, energy performance, deposit.

\footnotetext{
${ }^{1}$ Faculty of Chemistry and Chemical Technology, Al-Farabi Kazakh National University,

71, Al-Farabi Ave., 050040 Almaty, Kazakhstan

${ }^{2}$ The Combustion Problems Institute,

172, Bogenbaibatyr St., 050012 Almaty, Kazakhstan

larissa.rav@mail.ru

(C) Tulepov, M.; Sassykova, L.; Kerimkulova, A.; Tureshova, G.; Abdrakova, F.;

Zhapekova, A.; Sultanova, Z.; Spanova, G.; Tolep, D.; Gabdrashova, S.; Baiseitov, D., 2022
}

\section{Introduction}

Kazakhstan is among ten countries in which there are the largest coal deposits in the world, with $62 \%$ of deposits accounted for brown coal, and $38 \%$ for coal. ${ }^{1,2}$ The most profitable coal deposits in Kazakhstan, which are being intensively developed, are located in the central and northern part of the country. ${ }^{3}$ The reserves of brown coal in Kazakhstan are more than 12 billion tons. These are some deposits of the Karaganda basin, the Sarykol, Turgai, Kolzhatsky, Nizhne-Ili, Shubarkul, Lenger, Maikubensky, Oy Karagay, Kiyaktiansky and Karazhyra fields. $^{4,5}$

It is known that approximately $70 \%$ can be the content of fines in the coal produced and, as a rule, it cannot be used as a fuel. ${ }^{6,7}$ The steadily declining quality of mined steam coal is pushing for the solution of new technical problems: igniting and maintaining the burning of such coal; increase in its calorific value; waste disposal; constantly aggravating environmental problems. One of the cost-effective solutions for the use of low-quality coal and fine coal is the preparation of briquettes. Carrying out coal briquetting provides certain advantages: an increase in the size of the coal product; reduction of emissions into the atmosphere during combustion; obtaining high quality coal briquette with standard indicators; easiness of transportation and storage; high heat emission in the process of burning coal briquette; coal briquettes are easily ignited and burn for a quite long time; it solves the problem of spontaneous combustion of fines during storage. ${ }^{8-10}$ The material for the preparation of coal briquettes is a coal fine of dry, poorly fusible coals, which cannot be used for direct combustion in the furnace. ${ }^{11,12}$ The main task in the production of coal briquettes is to make the most complete mixing of coal fines with tar, which for economic reasons must be taken in a minimum amount, but, however, in such that a compact mass is obtained when pressing briquettes. ${ }^{13,14}$ The amount of resin needed to form briquettes depends on both the properties of the resin itself and the properties of the coal taken. 
One of the most important qualities of a fuel briquette ensuring their high liquidity is that they have by 1.5-1.7 times more complete combustion (efficiency) than lump coal of a similar grade. In addition, briquettes provide greater environmental friendliness of flue gases compared to coal. ${ }^{15-18}$

The purpose of this research is the development of briquetting technology of sub-standard coal of the Kazakhstan fields to produce high-quality briquette fuel. In this study, a modifying additive in the form of petroleum residues was selected that would allow synthesis of a binding composition for briquetting brown coal. The novelty of the work is the selection of a combustible cementator, which allows to perform qualitative burning of non-standard coals of the central region of Kazakhstan.

\section{Experimental}

The coals of the Oy Karagay field deposit of the Central region of Kazakhstan were chosen for the study of the briquettes production from coal and polymers. Coal briquettes were prepared according to the common technology, consisting of the coal grinding, drying to a certain moisture content, mixing with binders, heating coal charge, pressing and cooling. ${ }^{19-21}$ Waste PET, tar and tar with additives were used as a binder. The mixtures of solid polymer residues were previously subjected to heat treatment. Then, together with coal, mechanical treatment was carried out to a particle size of $>200 \mu \mathrm{m}$. Heat treatment of briquettes was carried out in cabinets of SNOL-3.5 with adjustable temperature in the range of $323-673 \mathrm{~K}$. The burning temperature was measured with a Raytek 3i 1M optical pyrometer. Toluene, benzene, alcohol benzene, naphthalene and acetone were used as solvents. The IR absorption spectra of the studied samples were measured on a PerkinElmer Spectrum 65 IR spectrometer in the region of $700-3600 \mathrm{~cm}^{-1}$, as well as on a UV-750U spectrophotometer in the region of 400 $4000 \mathrm{~cm}^{-1}$ in collapsible cuvettes (liquid samples) and in tablets of potassium bromide (solid samples). Changes in the surface and structure were detected using a NtegraTherma scanning electron microscope with light modes "on the light" and "on reflection".

Hydraulic automated press IP-100 was used for briquetting. Compression was performed in the closed cylindrical matrices (diameter of $10-25 \mathrm{~mm}$ ). The estimated number of briquetting components in a certain sequence was mixed to obtain a homogeneous mass and then was briquetted in a press under pressing pressure of $25 \mathrm{MPa}$, which corresponds to the pressure developed in industrial roller presses. To ensure the plasticity of the charge and liquefying the binder before briquetting, a fixed volume of water was added to it. The charge prepared for pressing was tested for moisture content. The strength of the briquettes was estimated by the crushing method on the IP-100 press with the maximum effort control. Determination of the strength characteristics was carried out after cooling the briquettes to room temperature.

Elemental composition of the initial coal of the $\mathrm{Oy}$ Karagay deposit on the basis of technical analyses is: sulphur $0.6-1.1 \%$; carbon $75-83 \%$; oxygen $15-37 \%$; hydrogen $3.0-6.5 \%$; nitrogen $0.7-1.2 \%$ and humic acids up to $80 \%$.

Energy characteristics of initial coals are necessary first of all for determination of optimum temperatures of drying and formation of final coal briquettes. The main purpose of calcining briquettes is to increase their hightemperature strength by producing coke, which "cements" coal particles. Qualitative characteristics of brown coal were obtained on the basis of technical analyses and technological tests with a pilot combustion. Energy characteristics of the source coal of the Oy Karagay deposit (Table) are: caloric content $28 \cdot 10^{3} \mathrm{~kJ} / \mathrm{kg}$; high calorific value $15 \cdot 10^{3} \mathrm{~kJ} / \mathrm{h}$; volatile $27.0-45.0 \%$ and analytical moisture $7.8 \%$.

\section{Results and Discussion}

The results of the SEM studies of the original coal (Fig. 1a) and coal after calcination (Fig. 1b) show that the formation of coal briquettes with a binder occurs as a result of adhesion of the coal particles with the binder. It is seen that in the initial coal after calcination, the size of its particles simultaneously decreases and aggregation of particles occurs with the formation of large aggregates reaching a size of $227.3-289.9 \mathrm{~nm}$. The SEM data of coal indirectly indicate surface changes after calcination, indicate aggregation processes, or confirm that these compounds belong to amorphous formations. In particular, according to SEM data, one can see the organic component of coal fines, which is a mixture of various $\mathrm{X}$ ray amorphous components, the presence and quantity of which vary in the order of metamorphism. The mechanical dispersion of a coal briquette with polyethylene terephthalate does not cause destruction of aggregates (Fig. 1c). PET waste is a semi-solid viscous mass that retains the state of aggregation at the temperature of 298-303 K. Consequently, when using them as a binder and obtaining a mixture of a homogeneous composition, heating to the melting point of $393-403 \mathrm{~K}$ will be required. 
Table. Technological indices of the Oy Karagay deposit coal

\begin{tabular}{|c|c|c|c|c|c|c|c|c|c|}
\hline \multicolumn{3}{|c|}{ Index, \% } & \multicolumn{3}{|c|}{ Content, \% } & \multirow{2}{*}{$Q_{s}^{a}, \mathrm{~kJ} / \mathrm{h}$} & $q, \mathrm{~kJ} / \mathrm{kg}$ \\
\cline { 1 - 7 }$W^{a}$ & $V^{a}$ & $A^{a}$ & $\begin{array}{c}\text { Sulfur } \\
\text { (total) }\end{array}$ & Nitrogen & Carbon & Oxygen & Hydrogen & & \\
\hline 7.8 & $27-45$ & 12.5 & $0.6-1.1$ & $0.7-1.2$ & $75-83$ & $15-37$ & $3.0-6.5$ & $15 \cdot 10^{3}$ & $28 \cdot 10^{3}$ \\
\hline
\end{tabular}

Note: $W^{a}, V^{a}, A^{a}$ are moisture, volatile matter and ash content in an analytical state, respectively; $Q_{s}^{a}$ is a high calorific value; $q$ is a caloric content.

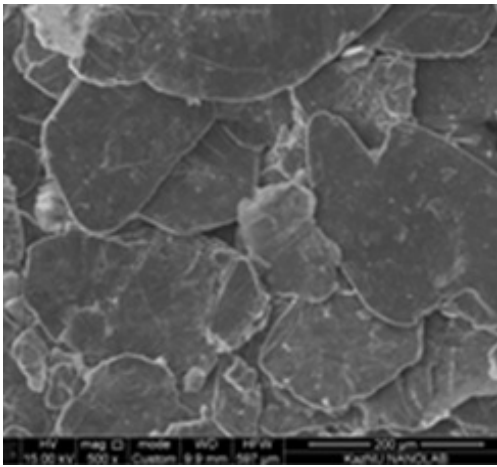

a)

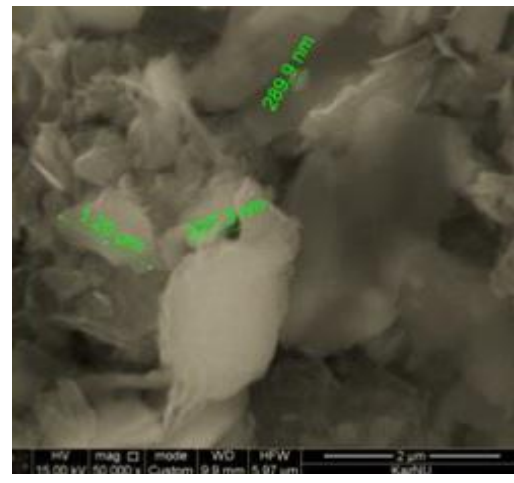

b)

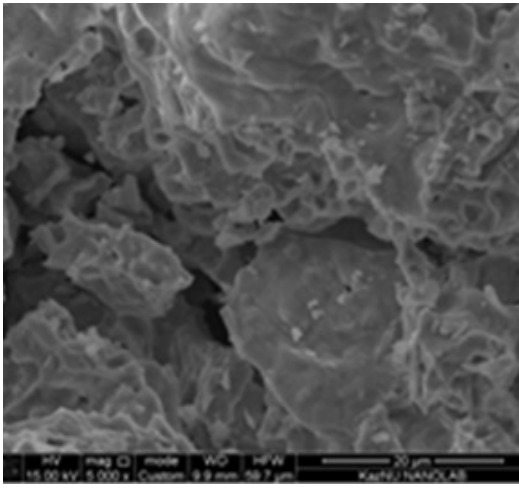

c)

Fig. 1. SEM images of original coal of Oy Karagay deposit (a); coal briquette based on coal from the Oy Karagay deposit after calcination (b) and coal briquettes with PET when the melting point is approx. 393-403 K (c)

The SEM data of coal with polyethylene terephthalate (Fig. 1c) show that these compounds belong to amorphous formations. It is seen that the organic component of the coal fines is a mixture of various X-ray amorphous components, the presence and quantity of which vary in a series of metamorphism. The XRD data of briquette analysis after calcination show that the main phase is the amorphous carbon phase with the mineral component in the form of iron oxide, silicon dioxide, calcite, feldspar and $\mathrm{Fe}_{2} \mathrm{SiO}_{4}$ (Fig.2). ${ }^{22}$

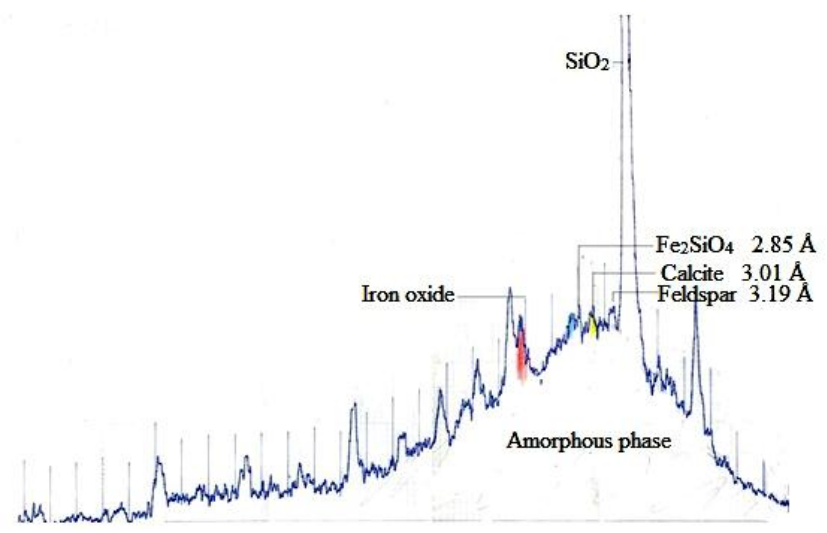

Fig. 2. XRD analysis of coal briquettes based on coal from the Oy Karagay deposit after calcination
IR spectroscopic data (Figs. 3 and 4) show that after heat treatment of coal, the number of saturated $\mathrm{CH}$ bonds in the form of methylene and methyl groups increased in the range of $2500-3500 \mathrm{~cm}^{-1}$. At the same time, a decrease in the absorption intensity in the region of $1500-1600 \mathrm{~cm}^{-1}$ is noticeable. This is explained by the fact that in the process of heat treatment, decomposition of the coal aromatic structure occurs, which interacts with the structure of the polymer. These changes are characterized by a decrease in the intensity of absorption in the region of $1500-1600 \mathrm{~cm}^{-1}$, and the appearance of new peaks in the region of $800-1400 \mathrm{~cm}^{-1}$ (Fig. 3). ${ }^{23}$ These changes are explained by the fact that the carboxyl groups, ketones and esters form the polymer and the number of methylene structures is destroyed. The formation of a fragment of the coal organic mass consists in the compilation of various functional groups of the selected compounds. Apparently, the growth of hydroxyl groups is due to the rupture of ether bonds, the increase in methyl groups is a consequence of the addition of ethylene from polyethylene, and the growth of carbonyls may be the result of acylation of aromatic coal fragments. When analyzing the distribution of oxygen in the structure of coal, several forms are found: $\mathrm{O}_{\text {phenolic }}$ (phenolic hydroxyls), $\mathrm{O}_{\mathrm{COOH}}$ (carboxyl groups), $\mathrm{O}_{\mathrm{C}=\mathrm{O}}$ (carbonyl oxygen), $\mathrm{O}_{\mathrm{OMe}}\left(\right.$ methoxy group $\left.-\mathrm{OCH}_{3}\right)$, etc. ${ }^{24-26}$ 


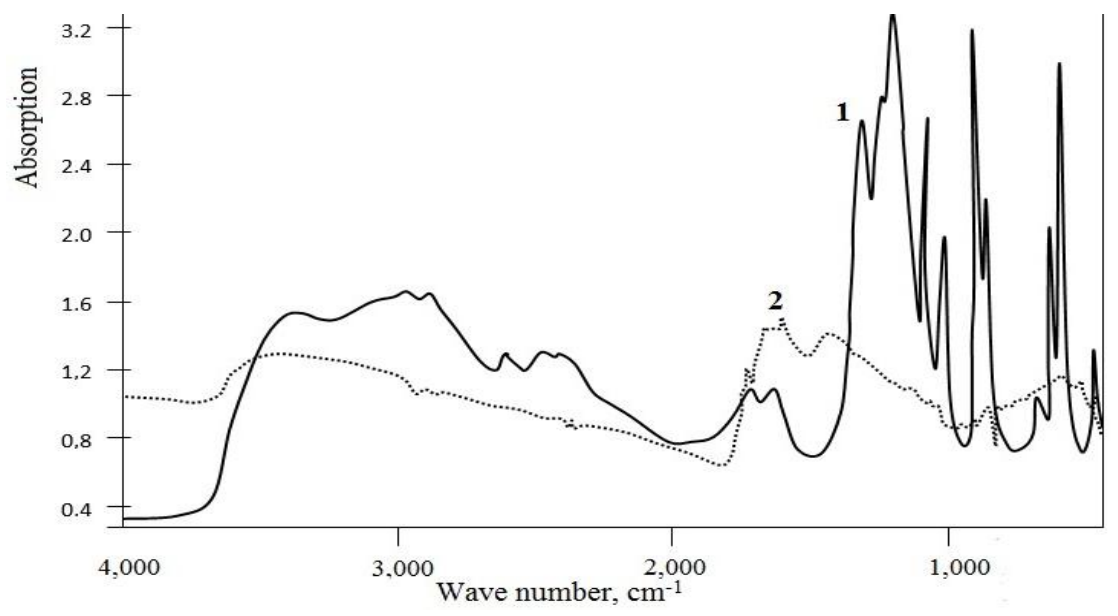

Fig. 3. IR spectra of the original coal sludge (1) and coal briquette with PET (2)

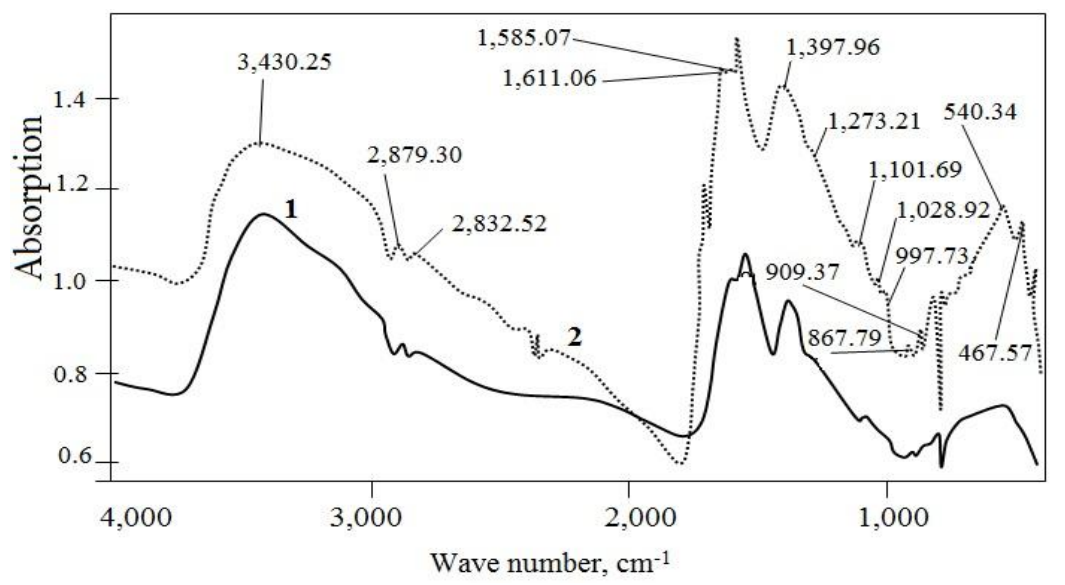

Fig. 4. IR spectra of coal with polymer: coal briquette with tar (1), coal briquette with a binder (2)

Studies of the briquettes physical parameters and the SEM data show that the thickness of the coal adsorption layer and the cohesion of the binder in thin layers play an important role in the formation of the structure and strength of the briquette. According to the SEM data, it can be assumed that at the optimum thickness of the film layer, the maximum manifestation of capillary forces and an increase in the adhesive interaction between the particles and the binder take place.

In this research, the change in the compressive strength of the fuel briquette with varying moisture content of the charge and pressing pressure was also investigated. It has been established that with decreasing particle size, their bond strength increases in a briquette. With an excess of moisture in the coal, sticking of the binder to the surface of the particles becomes difficult, and the strength of the briquettes decreases. With a very dry coal, the wettability of the particles surface by the binder deteriorates and its consumption increases. The optimum moisture content corresponding to the lowest binder consumption is determined empirically.
Carbon briquettes were tested for moisture resistance, the content of PET binder varied from 5 to $25 \%$. According to the test results, it was found that the optimal content of PET in a coal briquette is $15-19 \%$, and further increase in the proportion of binder is impractical for environmental and economic reasons. Fig. 5 shows the appearance of a coal briquette.

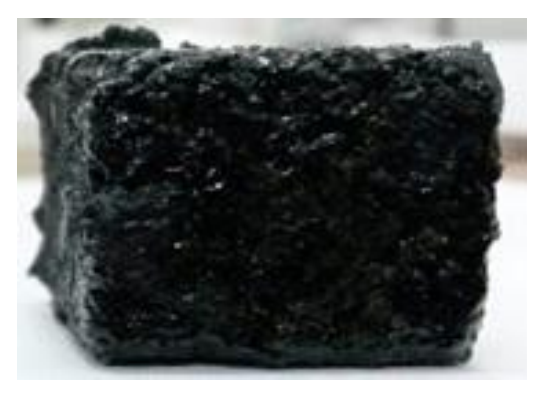

Fig. 5. General view of coal briquette

The main components of tar are oils that are not distilled off during the distillation of oil, petroleum resins, 
solid asphalt-like substances (asphaltenes, carbenes, carboids) and resinous substances of an acidic nature. The use of tar as a binder and cementing agent for coal briquetting is complicated by the excessive content of residual oils in its composition, which adversely affects the adhesive properties. ${ }^{27}$

To accelerate the oxidation processes and improve the adhesion ability of the coal-binder system, the tests on addition of carbon black as a cement grinder and structurally active additive to tar were carried out. Due to its adsorption properties and structure, carbon black is able to sorb part of low molecular weight oils and accelerate the oxidation of tar to the bituminous state during further thermal treatment.

The influence of the moisture content of coal on the mechanical properties of briquettes, which plays an important role in the mechanism of briquette formation, was studied. Moisture on the coal grains surface forms a hydrated film that affects the strength of the binder and coal. As a result of numerous experiments, it was found that with an excess of moisture a liquid film forms on the coal surface, preventing the binder from adhering firmly to the coal, while the wetting ability of the binder decreases and the mechanical strength of the briquettes decreases (Fig. 6).

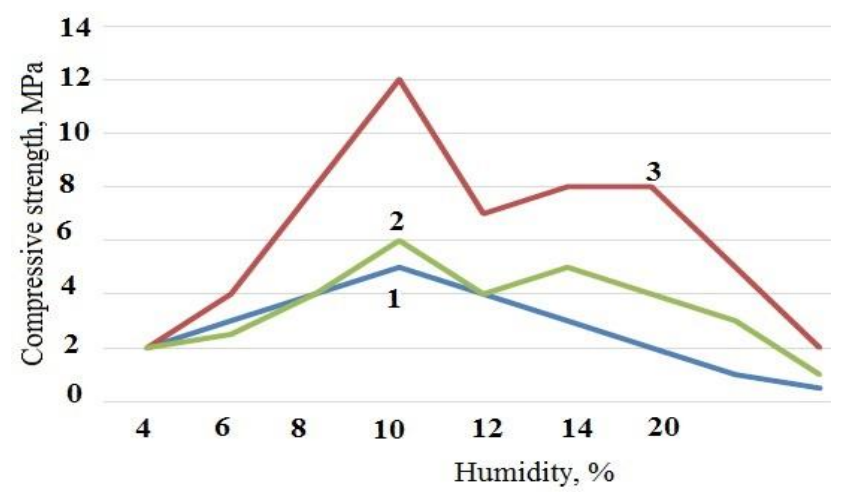

Fig. 6. The influence of the moisture content of coal on the strength of briquettes obtained at a pressing pressure of $50 \mathrm{MPa}(1), 100 \mathrm{MPa}(2)$ and $150 \mathrm{MPa}(3)$

The optimum value of the moisture content of the briquette was established by the values of the compressive strength of the samples at minimum and maximum pressing pressure. The results show that the maximum compressive strength is at the coal moisture content of $10-11 \%$. Fig. 6 shows that at waste humidity of 5-10\% and higher the durability and, respectively, the density of briquettes increases, but further increase of humidity affects durability of briquettes in the worst way. It is established that the most durable briquettes are obtained at the moisture content of the initial mixture about $10 \%$. With increasing humidity from 10 to $30 \%$, the strength of the briquettes decreases.
Thus, the quality of briquettes significantly depends on the moisture content of the original mixture. The optimum humidity is $10 \%$; with such humidity the best mechanical characteristics of the briquettes are achieved. The increase in moisture content of coal from 12 to $20 \%$ has a weakening effect on the adhesion between the coal and the binder due to the sharp disruption of the direct adsorption contacts in the interfacial zone, which leads to a drop in strength. Consequently, the optimum for briquetting is the humidity of the air-dry state of coal, which is in the range of $10-11 \%$.

The study of the heat treatment effect on the mechanical properties of briquettes (Fig. 7) show that the compressive strength of briquettes increases with the temperature of the final processing and reaches a maximum value at $503 \mathrm{~K}$ with an exposure at this temperature for $180 \mathrm{~min}$, a rise in temperature above $503 \mathrm{~K}$ results to ignition and destruction of briquettes.

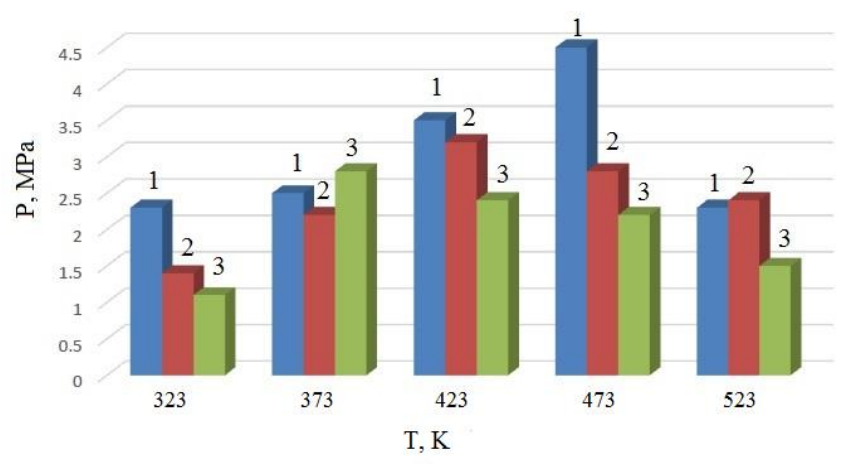

Fig. 7. The influence of heat treatment on the mechanical properties of briquettes: coal + carbon black (1); coal $+\operatorname{tar}(2)$ and coal + cellulose (3)

The compressive strength of the resulting briquettes increases to $16 \mathrm{MPa}$. The mechanical properties of the briquettes obtained using pure tar as a binder do not meet the requirements of state standards, the maximum compressive strength of these samples reaches $6 \mathrm{MPa}$.

Further, when the consumption of the binder is more than $15 \%$ (in the case of bitumen) and more than $30 \%$ (in the case of modified tar), the compressive strength begins to fall, which may be explained by the wall effect, i.e., the formation of a film on the surface of the sample, which prevents the oxidation of the binder in the product volume. This circumstance affects not only the strength of briquettes, but also determines the optimal consumption of the binder. ${ }^{28-30}$

The analysis of the results obtained in the work shows that the requirements of the state standards for lignite briquettes in terms of mechanical properties are met by the following compositions made at a pressing pressure of $150 \mathrm{MPa}$ and processed at the temperature of 
$503 \mathrm{~K}$ for $180 \mathrm{~min}$ : i) coal $90 \mathrm{wt} \%+$ bitumen $10 \mathrm{wt} \%$ (Pavlodar refinery, Kazakhstan), ii) coal $75 \mathrm{wt} \%+$ tar $15 \mathrm{wt} \%+$ sapropel $10 \mathrm{wt} \%$.

Studies on the effect of the granulometric composition of coal on the mechanical properties of briquettes (Fig. 8) show that an increase in compressive strength is especially noticeable in briquette samples containing coal with the smallest size (coal class $1.5 \mathrm{~mm}$ ). This is due to the fact that when briquetting fine coal, the number of interacting surface-active contact groups with the binder is maximized, the role of the so-called active centers on the solid surface increases. Also, the adsorption interaction at the interface of solid and liquid phases is increased; the diffusion of maltene binders into the pores and cracks of coal is more effective, which inevitably leads to the increase in strength.

As a result of research, it was established that the strength of composite formulations consisting of coal grains with fineness of $3 \mathrm{~mm}$ is about 3 times lower than the strength of briquettes obtained from $1.5 \mathrm{~mm}$ coal with the same briquetting parameters. This is due to the fact that large coal grains are destroyed during pressing, as well as the formation of additional surfaces that are not wetted with a binder. Despite the fact that samples made only from coal dust (grinding degree 1, Fig. 8) and mixtures (grinding degree 6, Fig. 8), exhibit higher compressive strength, their use for briquetting is not rational due to the introduction of labor-intensive grinding and sieving operations into the technological cycle. Therefore, for further research, coal with an optimal particle size of less than $2.5 \mathrm{~mm}$ was used.

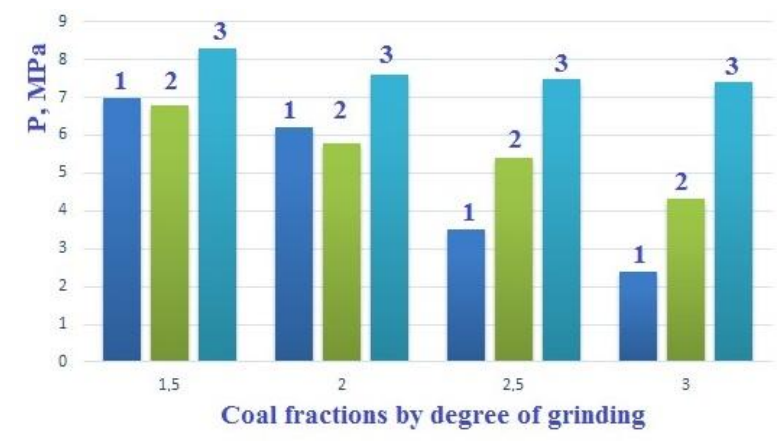

Fig. 8. Influence of coal grinding degree on a durability of briquettes, MPa: coal + tar (1); coal + technical carbon (2) and coal + PET (3)

The content of volatile substances is one of the important criteria for the characteristics of lignite fuels in terms of smoke. Briquettes obtained at optimum technological parameters and compositions, according to the content of volatile substances, belong to the category of smoky household solid fuels. ${ }^{31-34}$ The burning of the resulting fuel at $1123 \mathrm{~K}$ shows that the combustion of briquettes takes place within 383-386 K, and negligible allocation of soot in fire and combustion are observed for the briquette samples, containing both unmodified and modified tar.

The water absorption of briquettes is $1.8-2.5 \%$, while the residual strength of briquettes is reduced by 25 $30 \%$. This is due to the creation of water-repellent films from binders around the coal particle. Also, all samples are characterized by the lack of slipiness with each other. The remaining figures are close to the state standards. With the introduction of sapropel additives into tars, the heat of combustion of briquettes increases to $(28.4-28.9) \cdot 10^{3} \mathrm{~kJ} / \mathrm{kg}$.

\section{Conclusions}

The optimal process conditions and composite formulations of high-quality briquetted fuel from brown coals of Kazakhstan deposits have been established. In the laboratory, the optimal parameters for obtaining highquality fuel briquettes were: coal size $0-2.5 \mathrm{~mm}$; coal moisture $10-11 \%$; pressing pressure $150.0 \mathrm{MPa}$; processing temperature $503 \mathrm{~K}$; heat treatment time $180 \mathrm{~min}$.

Combustion of the obtained fuel at $1123 \mathrm{~K}$ showed that the ignition of briquettes occurs within 110-113 s, with insignificant emissions of soot during fire and burning are observed for briquette samples containing both unmodified and modified tar as a cementator.

The introduction of a modifying additive into the oil residues makes it possible to obtain a binding composition for briquetting brown coal, and the limiting factor for the use of the developed binder will be economic feasibility, which is determined both by the current prices for brown coal briquettes depending on the calorific value and ash content, and the prices for its components. Thus, the results of theoretical and experimental studies show the possibility and prospects of using raw materials of the Kazakhstan coal deposits for the development of a binder and cementator, which will allow to obtain a high-quality briquetted fuel.

\section{Acknowledgements}

The work was carried out under the project IRN AP05131088 "Development of technology of preparation of brown coal briquettes of substandard coal with a multipolymer binder" under the program: 217 "Development of science", subprogram: 102 "Grant financing of scientific research" of the Committee of Science of MES RK.

\section{References}

[1] Baiseitov, D.; Gabdrashova, Sh.E.; Magazova, A.N.; Dalelkhanuly, O. Hydrogenation of Coal of "Karazhira" Field: 
Optimal Catalysts and Thermogravimetric Researches. Int. J. Chem. Sci. 2016, 14, 244-250.

[2] Tulepov, M.I.; Baiseitov, D.A.; Sassykova, L.R.; Zhapekova, A.O.; Abdrakova, F.Yu.; Aknazarov, S.Kh.; Tureshova, G.O.; Spanova, G.A. Preparation of Coal Briquettes Based on Coal Fines with the Addition of Vinyl Chloride and Polyethylene Terephthalate. ARPN J. Eng. Appl. Sci. 2020, 15, 2311-2317. [3] Baiseitov, D.; Gabdrashova, Sh.E.; Akylbai, A.K.; Dalelkhanuly, O. Obtaining of Liquid Fuel from Coal in the Presence of the Polymers. Int. J. Chem. Sci. 2016, 14, 261-268.

[4] http://uglex.com/articles/232-zapasy-uglya-v-kazakhstane.html [5] Tulepov, M.; Mansurov, Z.; Sassykova, L.; Baiseitov, D.; Dalelhanuly, O.; Ualiev, Z. Research of Iron-containing Concentrates of Balkhash Deposit (Kazakhstan) for Processing of Low-grade Coal. J. Chem. Technol. Metall. 2019, 54, 531-538.

[6] Merrick, D. History of Coal Combustion and Conversion Technology. Coal Combustion and Conversion Technology. Energy Alternatives Series; Palgrave: London, 1984, pp 25-37.

https://doi.org/10.1007/978-1-349-06197-6 2

[7] Yemelyanova, V.S.; Dossumova, B.T.; Shakiyeva, T.V.; Sassykova, L.R.; Sendilvelan, S. Modified Aluminosilicate Catalysts Based on Cenospheres of Power Plants for Processing Fuel Oil into Light Fractions. Int. J. Mech. Prod. Eng. Res. Develop. 2019, 9, 10791086. https://doi.org/10.24247/ijmperdaug2019111

[8] Shakiyeva, T.V.; Sassykova, L. R.; Khamlenko, A.A.; Dossumova, B.T.; Sassykova, A.R.; Batyrbayeva, A.A.; Zhaxibayeva, Zh. M.; Kozhaisakova, M.A.; Azhigulova, R. N.; Sendilvelan, S. Composite Catalysts Based on Fly Ash of Thermal Power Plants and Natural Zeolite for Purification of Gas Emissions and Catalytic Cracking of Fuel Oil. ARPN J. Eng. Appl. Sci. 2021, 16, 1877-1885.

[9] Manina, T. S.; Fedorova, N.I.; Semenova, S.A.; Ismailov, Z.R. Processing Low-grade Oxidized Coal to Produce Effective Carbon Sorbents. Coke and Chemistry 2012, 55, 115-118. https://doi.org/10.3103/S1068364X12030027

[10] Widodo, Fatimah D.; Estiaty, L.M. Coal Blending Preparation for Non-carbonized Coal Briquettes. IOP C Ser. Earth Env., 18-19 October 2017, 118, conference 1, Bandung, Indonesia. https://doi.org/10.1088/1755-1315/118/1/012068

[11] Park, H.; Sahajwalla, V. Reduction Behavior of Carbon Composite Pellets Including Alumina and Silica at $1273 \mathrm{~K}$ and 1373 K. ISIJ Int. 2014, 54, 1256-1265.

https://doi.org/10.2355/isijinternational.54.1256

[12] Meincken, M.; Funk, S. Burning Characteristics of Low-cost Safety Charcoal Briquettes Made from Wood Residues and Soil for Domestic Use. Agroforest. Syst. 2015, 89, 357-363.

https://doi.org/10.1007/s10457-014-9772-8

[13] Maloletnev, A.S.; Gyul'maliev, A.M. Structure of Coal Hydrogenation Products Obtained in the Presence of Oil and Coal Paste-forming Agents. Solid Fuel Chem. 2013, 47, 231-233. https://doi.org/10.3103/S0361521913040095

[14] Stevenson, G.G.; Perlack, R.D. The Prospects for Coal Briquetting in the Third World. Energ. Policy 1989, 17, 215-227. https://doi.org/10.1016/0301-4215(89)90046-3

[15] Gabdrashova, Sh.E.; Rakhova, N.M.; Pustovalov, I.O; Elemesova, Zh.; Tulepov, M.I.; Korchagin, M.A.; Sassykova, L.R.; Sendilvelan, S.; Baiseitov, D.A. Preparation of Mechanically Activated Mixtures of Titanium with the Carbon Nanotubes and Study of their Properties under Thermal Explosion. Rasayan J. Chem. 2018, 11, 324-330. https://doi.org/10.7324/RJC.2018.1112017 [16] Antal, M.J.; Grønli, M. The Art, Science, and Technology of Charcoal Production. Ind. Eng. Chem. Res. 2003, 42, 1619-1640. https://doi.org/10.1021/ie0207919
[17] Somerville, M.A. The Strength and Density of Green and Reduced Briquettes Made with Iron Ore and Charcoal. J. Sustain. Metall. 2016, 2, 228-238. https://doi.org/10.1007/s40831-016-0057-5 [18] Khodakov, G.S. Influence of Fine Grinding on the Physicochemical Properties of Solids. Russ. Chem. Rev. 1963, 32, 386. https://doi.org/10.1070/RC1963v032n07ABEH001350

[19] Bazhin, V.Yu.; Kuskov, V.B. Production of Fuel Briquettes from Carbon Containing Materials. Proceedings of the XVIII International Coal Preparation Congress, Russia, Saint-Petersburg, 2016, 701. https://doi.org/10.1007/978-3-319-40943-6_108

[20] Maloletnev, A.S.; Mazneva, O.A.; Naumov, K.I.

Mechanochemical Activation of Coal from the Erkovetskoe Deposit and its Reactivity in a Liquefaction Process. Solid Fuel Chem. 2015, 49, 372-376. https://doi.org/10.3103/S0361521915060051

[21] Tulepov, M.; Sassykova, L.; Kerimkulova, A.; Tureshova, G.; Zhapekova, A.; Sultanova, Z.; Tursynbek, S.; Gabdrashova, Sh.; Baiseitov, D. Preparation of Coal Briquettes Based on Non-Standard Kazakhstan Coal with Various Additives and Determination of Their Quality. J. Chem. Technol. Metall. 2021, 56, 123-132.

[22] Shen, J.; Ling, K.; Zou, G.; Wang, Z. Reaction Mechanism of Coprocessing Coal and Heavy Oils. Coal Convers. 1999, 4, 5-9.

[23] Lu, G.; Yan, Y.; Colechin, M.; Hill, R. Monitoring of Oscillatory Characteristics of Pulverized Coal Flames through Image Processing and Spectral Analysis. IEEE T. Instrum. Meas. 2006, 55, 226-231. https://doi.org/10.1109/TIM.2005.861254

[24] Abotsi, G.M.K.; Bota, K.B.; Saha, G.; Mayes, S. Effects of Surface Active Agents on Molybdenum Adsorption onto Coal for Liquefaction. Prepr. Pap.-Am. Chem. Soc., Div. Fuel Chem. 1996, 41, 984-987.

[25] Kasaikina, O.T.; Lesin, V.I.; Pisarenko, L.M. Colloidal Catalysts on the Base of Iron(3+) Oxides for Oxidative Treatment of Biomass. Catal. Sustain. Energ. 2014, 2, 21-27. https://doi.org/10.2478/cse2014-0003

[26] Borowski, G.; Hycnar, J.J. Utilization of Fine Coal Waste as a Fuel Briquettes. Int. J. Coal Prep. Util. 2013, 33, 194-204.

https://doi.org/10.1080/19392699.2013.787993

[27] Baiseitov, D.; Tulepov, M.; Sassykova, L.; Gabdrashova, S.; Kudaibergenov, K.; Mansurov, Z. Physicomechanical Properties of Petrosorbents of the Phytogenesis. Revue Roumaine de Chimie 2017, 62, 249-253.

[28] Nameless: Binder for Improving Coal Gangue and Low-grade Coal. Fuel Energy Abstr. 2002, 43, 10. https://doi.org/10.1016/S01406701(02)80081-9

[29] Cook, A.C.; Sherwood, N.R. Classification of Oil Shales, Coals and Other Organic-rich Rocks. Org. Geochem. 1991, 17, 211-222. https://doi.org/10.1016/0146-6380(91)90079-Y

[30] Mochidzuki, K.; Soutric, F.; Tadokoro, K.; Antal, M.J.; Tóth, M.; Zelei, B.; Várhegyi, G. Electrical and Physical Properties of Carbonized Charcoals. Ind. Eng. Chem. Res. 2003, 42, 5140-5151. https://doi.org/10.1021/ie030358e

[31] De Korte, G.J. Processing Low-grade Coal to Produce High-grade Products. J. South. African Inst. Min.Metall. 2015, 115, 569-572.

[32] Tulepov, M.I.; Mansurov, Z.A.; Kazakov, Yu.V.; Abdrakova, F.Yu.; Sultanova, Z.L.; Rakhova, N.M.; Madiyev, S.S.; Golovchenko, O.Yu. ; Sassykova, L.R.; Tolep, D.M. et al.: Methods of Reducing the Front Performance Flame at the Underground Mines Works. Orient. J. Chem. 2018, 34, 3037. https://doi.org/10.13005/ojc/340645

[33] Gabdrashova, Sh.; Tulepov, M.; Pustovalov, I.; Sassykova, L.; Rakhova, N.; Spanova, G.; Hamzina, B.; Elouadi, B.; Kazakov, Yu. Preparation and Test of Slowly Burning Energy-intensive Materials 
with Time-delay Composition. J. Chem. Technol. Metallurg. 2019, 54, 650-656.

[34] Ellison, G.; Stanmore, B.R. High Strength Binderless Brown Coal Briquettes Part II. An Investigation into Bonding. Fuel Proc. Technol. 1981, 4, 291-304. https://doi.org/10.1016/03783820(81)90005-9

Received: August 07, 2019 / Revised: September 16, 2019 Accepted: December 05, 2019

\section{ПРИГОТУВАННЯ БРИКЕТІВ НА ОСНОВІ НЕКОНДИЦІЙНОГО ВУГІЛЛЯ КАЗАХСТАНСЬКИХ РОДОВИЩ}

Анотація. Розроблена технологія брикетування некондиційного вугілля казахстанських родовищ для отримання високоякісного брикетного палива. Вибрана модифікуюча добавка у вигляді нафтових залишків, яка дає можливість отримати зв язуюче для брикетування бурого вугілля. Матеріалом для приготування брикетів є вугільний дрібняк, одержаний $з$ сухого вугілля, щзо погано спікається, $і$ яке не може використовуватись для безпосереднього спалювання в печі. Визначено оптимальні параметри для отримання високоякісних паливних брикетів. Введення модифікуючої добавки до нафтових залишків дає можливість отримати зв язуюче для брикетування. Дослідження фізичних параметрів брикетів та дані SEM показали, що товщина адсорбиійного шару вугілля та зчеплення зв язуючого в тонких шарах відіграють важливу роль у формуванні структури та міиності брикету. Зроблено припущення, щзо за оптимальної товщини шару плівки має місце максимальний прояв капілярних сил $i$ збільшення адгезивної взаємодії між частинками $і$ зв язуючим. Органічний компонент вугільного дрібняку - че суміш різних рентгеноаморфних компонентів, наявність $і$ кількість яких змінюється в ряді метаморфізму. Показана можливість та перспективи використання місиевої сировини для розроблення високоякісного брикетованого буровугільного палива.

Ключові слова: вугілля, брикетування, зв'язуюче, гудрон, теплотворна здатність, енергетичні показники, родовище. 